\title{
PERNIKAHAN ADAT DAYAK NGAJU PERSPEKTIF HUKUM ISLAM (Studi di Kabupaten Gunung Mas Kalimantan Tengah)
}

\author{
Surya Sukti, Munib dan Imam S Arifin \\ Institut Agama Islam Negeri Palangka Raya, Indonesia \\ syaikhu@iain-palangkaraya.ac.id
}

Received:13-10-2020; Revised:22-12-2020; Accepted: 27-12-2020;

\begin{abstract}
Dayak traditional marriage is a solution for those who have problems doing marriage according to the marriage law, such as underage marriages, interfaith marriages, there are even those who are married in customary ways then they live together and after a long time carry out marriage according to Islamic law. From the findings in the field, there are those who marry according to custom and after having new children marry in Islam. This phenomenon is very interesting to discuss and research, especially from the perspective of Islamic law. The requirement for a Dayak customary marriage is 17 points and this is quite heavy for the bridegroom, so do not enforce it, especially for the less fortunate prospective groom. Considering that many of the traditional Dayak marriages originate from the Hindu Kaharingan religion and some of them are against Islamic law, it is better for those who are married to be Muslim, so when opening the lawang sekepeng drinking tuak is replaced by drinking milk or other halal drinks. If there is a customary law that is against Islamic law, then the customary law should be defeated, such as interfaith marriage and underage marriage as well as traditional marriage and then gather as husband and wife before marriage in Islam.
\end{abstract}

Keywords: Customary Marriage, Dayak Ngaju and Islamic Law.

\section{INTISARI}

Perkawinan adat dayak merupakan solusi bagi yang bermasalah melakukan perkawinan menurut undang-undang perkawinan, seperti nikah di bawah umur, nikah beda agama, bahkan masih ada yang nikah secara adat kemudian mereka hidup berkumpul dan setelah lama baru melaksanakan pernikahan secara syari'at Islam. Dari temuan di lapangan ada yang menikah secara adat dan setelah mempunyai anak baru menikah secara Islam. Fenomena ini sangat menarik untuk dibahas dan diteliti, apalagi ditinjau dari perspektif hukum Islam. Persyaratan pernikahan adat dayak ada 17 poin dan ini cukup berat bagi mempelai laki-laki, oleh sebab itu jangan dipaksakan terutama bagi calon mempelai laki-laki yang kurang mampu. Mengingat pernikahan adat dayak itu banyak bersumber dari agama Hindu Kaharingan dan di antaranya ada yang bertentangan dengan hukum Islam, sebaiknya bagi yang menikah itu beragama muslim maka ketika membuka lawang sekepeng itu minum tuak diganti dengan minum susu atau minuman lainnya yang halal. Jika ada hukum adat yang bertentangan dengan hukum Islam maka sebaiknya hukum adat dikalahkan, seperti nikah beda agama dan nikah di bawah umur serta nikah adat kemudian berkumpul sebagaimana suami isteri sebelum nikah secara Islam.

Kata Kunci: Pernikahan Adat, Dayak Ngaju dan Hukum Islam. 


\section{A. Pendahuluan}

Adat perkawinan di Indonesia banyak terdapat macam ragamnya. Setiap suku bangsa ada memiliki adat perkawinan masing-masing. Diantara adat perkawinan itu ada yang hampir serupa terutama pada suku-suku yang berdekatan, tetapi ada pula yang berlainan. Pada dasarnya, adat perkawinan suku bangsa Indonesia bertolak dari warga masyarakat bahwa perkawinan adalah suatu ikatan yang sakral dan merupakan salah satu sunah dan karuniyah Allah SWT yang tidak bisa dihindari oleh manusia. Pernikahan bukan sekedar ikatan antara seorang laki-laki dan seorang perempuan tetapi juga merupakan proses penyatuan dua keluarga.

Perkawinan adat suku Dayak menjadi ritual wajib bagi masyarakat setempat agar menjunjung tinggi nilai-nilai adat dan budaya leluhur. Dalam istilah perkawinan adat Dayak Ngaju sudah menjadi singer atau pedoman dalam kehidupan mereka. Sebab itu agama apapun pelaksanaan perkawinan adat ini harus terus dilestarikan dan dibudayakan. ${ }^{1}$

Pada umumnya orang dayak sebelum melakukan Pernikahan ada dilaksanakan pernikahan adat, banyak hal-hal yang disiapkan oleh calon mempelai laki-laki, mulai dari tanah atau lahan, perlengkapan rumah tangga dan sarana kehidupan pasca pernikahan.

Disamping itu juga ada perjanjian bahwa jika salah satu pihak ada prilaku yang dapat merusak keharmonisan rumah tangga seperti berselingkuh maka akan dikenakan jipen oleh mantir adat sesuai dengan perjanjian, biasanya pihak yang melanggar janji akan dikenakan denda berkisar Rp 30 juta - 50 juta, sesuai dengan kesepakatan kedua belah pihak.

Tradisi masyarakat dayak dalam perkawinan banyak dipengaruhi budaya masyarakat Hindu Kaharingan, adapun salah satunya adalah jalan hadat dimana pihak mempelai laki-laki menyiapkan yang terdiri dari perangkat benda-benda seperti Garantung Kuluk Pelek(Gong) dan Lamiang Turus Pelek, perhiasan dan barang berharga lainnya. Lamiang Turus Pelek pada jaman dulu wajib ada karena pada saat upacara Haluang Hapelek (proses dialog penagihan dan pembayaran Jalan Hadat perkawinan) benda inilah yang akan menjadi tonggak perjanjian kedua mempelai dihadapan Ranying Hatalla/Tuhan Yang Maha Esa. ${ }^{2}$

Berdasarkan penjelasan di atas tentunya cukup berat bagi calon mempelai laki-laki untuk menikah karena banyaknya persyaratan yang harus dipenuhi. Kemudian yang menjadi masalah adalah masih ada warga masyarakat yang menikah secara adat kemudian mereka hidup bersama sebagai suami isteri, bahkan ada yang sampai punya anak satu baru menikah secara Islam. Tentu saja praktik yang seperti ini tidak sesuai dengan syariat Islam.

Berdasarkan uraian di atas maka permasalahan ini layak untuk diangkat dalam sebuah jurnal dan juga peneliti akan memberikan solusi untuk mengatasi masalah ini.

\section{B. Metode Penelitian}

Penelitian ini menggunakan pendekatan kualitatif deskriptif. Pendekatan merupakan metode atau cara mengadakan penelitian sebagaimana halnya penelitian non eksperimen yang dari segi tujuannya akan diperoleh jenis atau tipe yang di ambil. ${ }^{3}$ Pendekatan kualitatif

\footnotetext{
${ }^{1}$ Thoyib, "Eksestensi Perjanjian Perkwinan Adat Dayak Ngaju Dalam Mencegah Perceraian Pasca Putusan Pengadilan Agama Palangka Raya”, Tesis, (Pasca Sarjana IAIN Palangka Raya, tidak diterbitkan, 2017 ), 3.

${ }^{2}$ Sadiani, dkk, Jalan Hadat Perkawinan Dayak Ngaju Suatu Upaya Mengawal Harmonisasi Rumah Tangga Dalam Perspektif Hukum Perkawinan Islam, Hasil Penelitian, Tidak Terbit, (IAIN Palangka Raya, 2017 ), 1.

${ }^{3}$ Santi, "Akibat Hukum Putusan Mahkamah Konstitusi Nomor 46/PUU-VIII/2010 terhadap Hak Anak Biologis dalam Tinjauan Hukum Islam (Pesrpektif Hakim Pegadilan Agama Palangka Raya)”, Skripsi, (IAIN Palangka Raya, 2014), 43.
} 
deskriptif dalam penelitian ini dimaksudkan agar dapat mengetahui dan menggambarkan apa yang terjadi di lokasi penelitian secara lugas dan rinci. ${ }^{4}$

\section{Pembahasan}

1. Teori Akulturasi

Akulturasi menurut kajian antropologi memiliki beberapa pengertian (Aculturation atau Culture Conttact). Ini semua menyangkut proses sosial yang timbul apabila suatu kelompok manusia dengan suatu kebudayaan tertentu dihadapkan pada unsur-unsur suatu kebudayaan asing sehingga unsur-unsur asing tersebut lambat laun diterima dan di olah dalam kebudayaan sendiri, tanpa menyebabkan hilangnya kepribadian kebudayaan itu ${ }^{5}$.

Akulturasi dapat dideskripsikan sebagai suatu tingkat dimana seorang individu mengadopsi nilai, kepercayaan, budaya dan praktek-praktek tertentu dalam budaya baru. Menurut Redfield, Linton dan Herskovits akulturasi memahami fenomena yang terjadi ketika kelompok individu yang memiliki budaya yang berbeda datang ke budaya lain kemudian terjadi kontak berkelanjutan dari sentuhan yang pertama dengan perubahan berikutnya dalam pola kultur asli atau salah satu dari kedua kelompok.

Mulyana menganggap bahwa definisi akulturasi itu merupakan definisi otoritatif yang telah menjadi inspirasi bagi ilmuwan lainnya untuk memberikan definisi akulturasi yang serupa, yaitu bahwa akulturasi adalah suau bentuk perubahan budaya yang diakibatkan oleh kontak kelompokkelompok budaya, yang menekankan penerimaan pola-pola dan budaya baru dan ciri-ciri masyarakat pribumi oleh kelompok-kelompok minoritas. ${ }^{6}$

\section{Teori 'urf}

'urf secara bahasa berarti sesuatu yang dipandang baik dan diterima oleh akal sehat. Sedangkan secara istilah sebagaimana dikatakan oleh Abdul Karim Zaidah dalam Satria Effendi dan M. Zein adalah sesuatu yang tidak asing bagi suatu masyarakat tertentu yang telah menjadi suatu kebiasaan dan menyatu dengan kehidupannya. ${ }^{7}$ Dalam perspektif syara ${ }^{\text {ee }}$, menurut Abdul Wahab Khalaf menjelaskan bahwa tidak ada terdapat perbedaan antara ,urf dengan adat. Adat terbentuk dari kebiasaan manusia menurut derajat mereka, baik secara umum maupun secara khusus. ${ }^{8}$

'urf merupakan sumber hukum yang diambil oleh mazhab Hanafy dan Maliky, yang berada diluar lingkup nash. 'Urf (tradisi) adalah bentuk muamalah (hubungan kepentingan) yang telah menjadi adat kebiasaan dan telah berlangsung ajeg (konstan) di tengah masyarakat. ${ }^{9}$

Mustofa Ahmad Al Zarqo yang dikutip oleh Nasruh Haroen, mengatakan bahwa 'urf merupakan bagian dari adat, karena adat lebih umum. Suatu ' $u r f$ harus berlaku pada kebanyakan orang di daerah tertentu, bukan pribadi ataupun kelompok tertentu, dan bukan kebiasaan alami, tetapi muncul atas dasar pemikiran dan pengalaman. Istilah ushul fikih lebih menggunakan term

\footnotetext{
${ }^{4}$ Ibid.

${ }^{5}$ Koentjaraningrat, Pengantar Ilmu Antropologi, (Jakarta: Rineka Cipta, 2005), 155.

${ }^{6}$ Dalam Deddy Mulyana dan Jalaluddin Rakhmat (ed.), Komunikasi Antarbudaya, (Bandung: PT. Remaja

${ }^{7}$ Satria Effendi dan M Zein, Ushul Fiqh, (Jakarta: Kencana, 2005), 21.

${ }^{8}$ Abdul Wahhab Khalaf, Ilmu Ushul Fikih, (Jakarta: Darul Qalam, 2002), 58.

${ }^{9}$ Muhammad Abu Zahrah, Ushul Fiqh, (Jakarta: Pustaka Firdaus, 2007), 416.
} Rosdakarya, 2001), 159. 
'urf daripada adat. ${ }^{10}$ Oleh karena itu, peneliti menggunakan term 'urf sebagai teori dalam hukum Islam untuk menganalisa permasalahan 'urf dalam perjanjian perkawinan adat Dayak Ngaju.

Para ulama sepakat bahwa 'urf shahih dapat dijadikan hujjah selama tidak bertentangan dengan syara'. Mazhab Maliki lazim memperkenalkan dalam mazhabnya bahwa kebiasaan amal ulama Madinah dapat dijadikan hujjah. Dalam mazhab Syafi'i dikenal istilah qaul qadim dan qaul jadid. Pada suatu kejadian Imam Syafi'i menetapkan hukum yang berbeda antara di Makkah (qaul qadim) dengan setelah ia berada di Mesir (qaul jadid). Hal ini menunjukkan bahwa mazhab di atas berhujjah dengan 'urf.'

\section{Teori Asimilasi Budaya}

Asimilasi adalah suatu proses sosial yang terjadi pada berbagai golongan manusia dengan latar belakang kebudayaan yang berbeda setelah mereka bergaul secara terus menerus, sehingga sifat khas dari unsur-unsur kebudayaan golongan-golongan itu masing-masing berubah menjadi unsur-unsur kebudayaan campuran, demikian menurut Koentjaraningrat ${ }^{12}$. Selanjutnya ia merincikan bahwa asimilasi timbul jika ada:

a. Ada golongan-golongan manusia dengan latar belakang kebudayaan berbeda;

b. Saling bergaul langsung secara terus menerus dalam waktu yang lama;

c. Kebudayaan-kebudayaan golongan-golongan yang berbeda tadi masing-masing berubah sifat khasnya dan juga unsur-unsurnya masing-masing dan berubah wujudnya menjadi unsur-unsur kebudayaan campuran. ${ }^{13}$

Pendapat lain Asimilasi adalah proses perubahan pola kebudayaan untuk menyesuaikan diri dengan mayoritas. ${ }^{14}$ Menurut Danadjaya, proses pembauran suatu budaya biasanya melalui asimilasi yang melalui dua proses, yaitu; asimilasi tuntas satu arah dan asimilasi tuntas dua arah. Asimilasi tuntas satu arah yaitu seseorang atau kelompok mengambil alih budaya dan jati diri kelompok dominan dan menjadi bagian dari kelompok itu. Asimilasi tuntas dua arah dapat berlangsung manakala dua atau lebih kelompok etnik saling memberi dan menerima budaya yang dimiliki oleh setiap kelompok etnik.

\section{Konsep Perkawnan Adat Dayak}

Perkawinan merupakan suatu yang sangat penting, suatu detik tatkala hubungan persaudaraan diperluas dan berubah. Perkawinan juga merupakan pelebaran menyamping tali ikatan antara dua kelompok himpunan yang tak bersaudara atau pengukuhan keanggotaan di dalam suatu kelompok endogam bersama. ${ }^{15}$

Perkawinan menurut hukum agama adalah perbuatan yang suci yaitu suatu ikatan antara dua pihak dalam memenuhi perintah dan anjuran Tuhan Yang Maha Esa, agar kehidupan berkeluarga dan berumah tangga, serta berkerabat berjalan dengan baik sesuai dengan agama

${ }^{10}$ Nasrun Haroen, Ushul Fiqh 1, (Jakarta: Logos, 1996), 98.

${ }^{11}$ Djazuli, Ilmu Fiqh, (Jakarta: Pranata Media Group, 2010), 128.

12 Koentjaraningrat, 160.

${ }^{13} \mathrm{Ibid}, 255$.

${ }^{14}$ Soejono Soekanto, Sosiologi: Suatu Pengantar, (Jakarta: Rajawali Grafindo Persada, 1983), 38, dikutip dari H. Khomsahrial Romli, Akulturasi dan Asimilasi, 3.

${ }^{15}$ Hildred Geertz, Sebagaimana dikutif oleh Ahrajal, dkk, Makalah dengan Judul: "Perubahan Pernikahan Adat Suku Bungku di Desa Bahomoleo Kecamatan Bungku Tengah Kabupaten Morowali”, Tidak Terbit, $1983,3$. 
masing-masing. Jadi perkawinan ini bisa dikatakan perikatan jasmani dan rohani yang membawa akibat hukum terhadap agama yang dianut calon mempelai dan keluarga kerbatnya. ${ }^{16}$

Perkawinan menurut adat atau perkawinan secara adat bertujuan untuk mengatur hidup dan perilaku hidup bahadat/beradat, mengatur hubungan manusia berlainan jenis kelamin guna terpeliharanya ketertiban masyarakat agar melakukan perbuatan-perbuatan yang baik dan tidak tercela, menata kehidupan berumah tangga yang baik sejak dini, tertata dengan baik dan santun, beradab dan bermartabat, menjamin kelangsungan hidup suatu suku/puak dan medapatkan keturunan yang sehat jasmani dan rohani serta menata garis keturunan yang teratur, menetapkan status sosial dalam masyarakat, menyelesaikan permasalahan-permasalahan yang terjadi dalam pergaulan muda-mudi supaya terhindar dari cela ataupun kutuk yang berdampak luas, menyelesaikan permasalahan yang berdampak pada komplik internal, eksternal dan antarsuku. ${ }^{17}$

Mengingat betapa pentingnya perkawinan adat tersebut bagi orang Dayak, setiap prosesi perkawian adat harus dilaksanakan seperti 1)Panganten Haguet, 2) Penganten Mandai (Mambuka Lawang Sakepeng, Mamapas, Haluang Hapelek, Manyaki Panganten/Panganten Hatatai), 3) Jalan Hadat Perkawinan Suku Dayak Ngaju.

Hal ini dilakukan turun-temurun untuk memelihara nilai budaya agar tidak tergerus oleh kemajuan jaman dan tingginya arus modernisasi yang melanda kehidupan di abad moderen ini. Pelestarian nilai budaya yang terkandung di dalamnya tidak lepas dari perwujudan nilai-nilai yang ada dalam kehidupan dan kepatuhan terhadap norma yang berlaku dalam masyarakat. ${ }^{18}$

\section{Proses sebelum Pernikahan}

\section{a. Hakumbang Auh}

Hakumbang Auh adalah cara awal dari prosesi perkawinan dengan maksud penyampaian niat seorang pria kepada seorang gadis yang diinginkan menjadi isterinya. Dalam kebiasaan masyarakat suku Dayak Ngaju, jika seorang pemuda berkehendak mengambil seorang gadis untuk dijadikan sebagai isterinya maka dia akan menyampaikan maksudnya terlebih dahulu kepada orang tuanya. Apabila disetujui maka selanjutnya orang tuanya akan memilih seseorang sebagai perantara yang bertugas menghubungi keluarga si gadis. Perantara ini disebut Uluh Helat atau biasa juga disebut Saruhan atau juga dapat disebut Tatean Tupai. Maksud hati dan keinginannya disampaikan kepada keluarga si gadis melalui perantara tersebut.

\section{b. Mamanggul}

Tahap ini merupakan kelanjutan dari Hakumbang Auh yaitu cara meminta si gadis secara resmi setelah pihak keluarga si pria mengetahui bahwa keinginan hati mereka diterima oleh pihak si gadis. Pada acara ini pihak pria akan menyerahkan beberapa barang sebagai bukti kesungguhan hati dan keseriusan mereka. Antara lain berupa sebuah Balanga (guci asli Cina) atau sebuah gong.

\footnotetext{
16 Ibid.

${ }^{17}$ Lelay Nangkai Puji, "Nilai Budaya Dalam Tradisi Lisan Pernikahan Adat Dayak Maanyan Di Kalimantan Tengah (Cultural Value in Oral Tradition of Dayak Manyan Customary Marriage in Central Kalimantan)", Makalah 102.

18 Ibid., 103.
} 
Pada acara ini kedua pihak membicarakan waktu pelaksanaan peminangan, yaitu Maja Misek. Dalam perkembangannya yang berlaku sekarang, bukti Mamanggul tidak lagi berupa gong melainkan berupa Duit Panggul. Pada kesempatan ini dibuat sebuah kesepakatan. Kesepakatan ini dapat berupa lisan maupun tertulis yang dibuat dalam bentuk sebuah surat perjanjian yang disebut surat Panggul. Jika pihak keluarga si gadis kemudian menolak maka barang bukti mamanggul tidak dikembalikan kepada pihak si pemuda.

\section{c. Maja Misek}

Maja berarti bertamu atau bertandang. Misek berarti bertanya, istilah Maja Misek disini maksudnya adalah acara pertemuan antara keluarga si pemuda dengan keluarga si gadis. Dalam pertemuan itu mereka mengambil kesepakatan bersama tentang: (1) Waktu atau jadwal pelaksanaan pesta perkawinan, (2) Syarat-syarat perkawinan yang disebut Jalan Hadat, (3) Besarnya Palaku yaitu mas kawin yang harus diserahkan, (4) Biaya pesta perkawinan dan bagaimana pembagiannya, (5) Sanksi atau denda yang dikenakan jika terjadi pembatalan atau penundaan oleh salah satu pihak, (6) Kesepakatan mereka merupakan perjanjian yang kemudian dituangkan dalam surat perjanjian Pisek.

\section{d. Mananggar Janji atau Mukut Rapin Tuak}

Mananggar Janji berarti memastikan janji, yaitu kedua belah pihak bertemu lagi secara khusus untuk memastikan kapan waktu pelaksanaan perkawinan. Jika pada saat Maja Misek telah ditentukan perkiraan bulannya saja, maka pada saat mananggar janji ini dibicarakan tanggal perkawinannya. Pada kesempatan ini pihak calon pengantin pria menyerahkan biaya perkawinan, antara lain : (1) Biaya membuat minuman tuak (Rapin Tuak), (2) Biaya pesta yang disebut Bulau Ngandung atau Panginan Jandau, (3) Jangkut Amak atau perlengkapan tidur dan isi kamar tidur.

\section{Proses Pernikahan Adat Dayak}

Pelaksanaan perkawinan yang dimaksud disini adalah upacara-upacara yang dilaksanakan sejak dari rumah penganten pria sampai dengan peresmian perkawinan mereka di rumah penganten wanita. Berikut adalah tahapan pelaksanaan perkawinan adat suku Dayak Ngaju:

\section{a. Panganten Haguet}

Panganten Haguet adalah acara penganten pria saat berangkat menuju rumah penganten wanita sesuai dengan kesepakatan mengenai pelaksanaan perkawinan maka pada hari yang telah ditetapkan, biasanya tiga hari setelah upacara Manyaki Rambat, ataupun juga pelaksanaan upacara Manyaki Rambat ini bisa juga dilaksanakan sebelum keberangkatan penganten laki-laki ke tempat penganten perempuan.

\section{b. Panganten Mandai}

Istilah Mandai sama dengan Manyakei yang artinya naik. Arti penganten Mandai atau penganten Manyakei disini adalah kedatangan penganten pria di rumah penganten wanita. Ketika penganten pria dan rombongannya tiba, beberapa kegiatan yang dilakukan adalah :

\section{c. Mambuka Lawang Sakepeng}

Lawang Sakepeng adalah semacam pintu gerbang atau gapura dari pelepah daun kelapa yang diberi rintangan benang. Pada rintangan benang penghalang dipasang bunga 
warna warni agar indah dan nampak semarak. Penganten pria dan rombongannya tidak boleh masuk ke halaman rumah sebelum membuka Lawang Sakepeng tersebut.

Caranya adalah dengan memutuskan benang-benang perintang oleh pesilat-pesilat yang dipilih mewakili masing-masing pihak dengan diiringi tabuhan gendang dan gong. Ditampilkannya pesilat dari keduabelah pihak mengandung makna bahwa dalam kehidupan rumah tangganya, kedua mempelai akan bersama-sama mengatasi persoalan yang datang sehingga dapat hidup rukun, saling membantu dan bekerjasama.

Adapun makna dari upacara mambuka Lawang Sakepeng ini adalah untuk menjauhkan semua rintangan dan malapetaka yang dapat menimpa kedua mempelai dalam membina rumah tangga.

\section{d. Mamapas}

Mamapas adalah upacara pembersihan secara simbolis bermakna agar penganten, rumah dan lingkungan tempat dilaksanakannya upacara perkawinan dapat bersih dari segala yang tidak baik dan terhindar dari hal-hal yang buruk yang ditimbulkan oleh roh-roh jahat yang disebut Pali Endus Dahiang Baya.

Bersamaan dengan upacara Mamapas ini, setelah tali perintang Lawang Sakepeng putus maka penganten pria dan rombongannya dipersilahkan memasuki halaman. Di depan pintu rumah mempelai pria akan diupacarai lagi dengan taburan beras dan bunga rampai serta prosesi penginjakan telor ayam.

Selanjutnya mempelai laki-laki dan rombongan dipersilahkan masuk rumah. Bagi mereka disediakan tempat khusus untuk beristirahat sambil menunggu acara selanjutnya.

\section{e. Haluang Hapelek}

Upacara Haluang Hapelek adalah semacam diaolog antara para wakil dari pihak penganten pria dan wanita. Tujuan utama dari acara ini adalah menagih Jalan Hadat, yaitu syarat-syarat dalam rangka perkawinan yang harus diserahkan oleh pihak penganten pria kepada penganten wanita. Masing-masing pihak membentuk kelompok tersendiri, sebagai utusan yang bertindak sebagai Luang. Masing-masing pihak dapat menunjuk 5 (lima) atau 7 (tujuh) orang wakil sebagai utusan.

Luang atau utusan dari pihak penganten pria disebut dengan Tukang Sambut, yaitu pihak yang menjawab sanggup tidaknya memenuhi tuntutan pihak penganten wanita. Adapun luang dari pihak wanita disebut Tukang Pelek, yaitu pihak yang mengajukan tuntutan. Luang adalah orang yang pekerjaannya mondar-mandir menghubungi dua pihak untuk mencari kesesuaian pendapat.

\section{f. Panganten Hatatai}

Inti upacara ini adalah upacara pengukuhan perkawinan bagi masyarakat Hindu Kaharingan suku Dayak Ngaju. Pada bagian inilah yang biasanya tidak dilaksanakan oleh masyarakat Dayak suku Dayak Ngaju yang non Hindu Kaharingan, namun masih melangsungan tata cara perkawinan sesuai tradisi leluhurnya. Upacara ini dipimpin oleh seorang Basir. Manyaki berarti mengoleskan darah hewan korban ke beberapa bagian tubuh kedua mempelai oleh Basir. Adapun istilah Penganten Hasaki berarti kedua mempelai dipoles dengan darah.

Pada acara ini kedua mempelai duduk di atas sebuah gong sambil memegang sebatang pohon sawang (Ponjon Andong) yang diikat bersamaan dengan Dereh Uwei (sepotong 
rotan) dan Rabayang (tombak bersayap/sejenis tri sula). Jari telunjuk mereka menunjuk ke atas sebagai tanda bahwa mereka berdua bersaksi kepada Ranying Hatalla Langit/Tuhan Yang Maha Esa. Kaki mereka menginjak jala dan batu asah sebagai tanda bahwa mereka berdua juga bersaksi kepada penguasa alam bawah.

Basir melakukan upacara manyaki mamalas dengan mengoleskan darah hewan korban, minyak kelapa, tanah, air dan beras serta tampung tawar. Behas (beras) Hambaruan diletakkan di atas ubun-ubun kedua mempelai. Upacara itu bermakna bahwa kedua mempelai disucikan, sehingga dalam menjalani kehidupan berumah tangga mereka senantiasa sehat, selamat dan memperoleh rejeki.

\section{Analisis Hukum Islam terhadap Perkawinan Adat Dayak}

Pada praktiknya perkawinan adat dayak tidak hanya dilakukan oleh warga masyarakat non muslim, tapi juga bagi yang beragama muslim. Padahal dalam prosesi pernikahan adat dayak ada perbuatan yang bertentangan dengan agama Islam. Sebagaimana hasil wawancara dengan Jainal Rakhim, pemuda yang pernah melaksanakan pernikahan secara adat dayak. Jainal Rakhim menuturkan sebagai berikut:

Pernikahan adat dayak banyak yang bernuansa agama kaharingan diantaranya ada yang tidak sesuai dengan ajaran Islam, misalnya ketika acara membuka lawang sekepeng, pada acara ini salah satu ritualnya minum tuak. ${ }^{19}$

Walaupun minum tuak pada saat acara pernikahan adat dayak ini bertujuan untuk melaksanakan adat atau tradisi yang sudah turun temurun, tapi bagi yang beragama Ismlam hukumnya tetap haram.

Pada kenyataannya juga ada yang melaksanakan pernikahan secara adat kemudian mereka berkumpul hidup serumah, setelah beberapa tahun kemudian bahkan sudah punya anak anak 1 orang baru melaksanakan pernikahan secara Islam.

Praktik yang seperti ini tentu saja tidak sesuai dengan hukum Islam, kalau memang ingin melaksanakan pernikahan secara adat dayak maka sebaiknya setelah dilaksanakan pernikahan secara adat dayak kemudian dilanjutkan secara Islam. Dan pelaksanaannya sebelum mempelai berkumpul sebagaimana suami isteri.

Pernikahan adat memiliki perbedaan prinsipil dengan pernikahan secara Islam. Yang mana pernikahan secara Islam harus memenuhi rukun dan syarat-syaratnya. Adapun rukun-rukunnya ada lima: calon suami, calon isteri, wali, dua orang saksi dan ijab qabul. Seorang calon suami yang akan menikah harus memenuhi syarat: bukan mahram dari calon isteri, tidak terpaksa, jelas orangnya dan tidak sedang ihram haji.

Syarat-syarat calon isteri yang akan menikah tidak ada halangan syar'i, yaitu, tidak bersuami, bukan mahram, tidak sedang dalam iddah. Pernikahan adat tidak menggunakan wali dan saksi sebagaimana pernikahan menurut Islam. Begitupun sebaliknya kepala adat sebagai wali nikah tidak dikenal dalam islam, Adat kebiasaan dapat dilaksanakan dan menjadi hukum jika tidak bertentangan dengan hukum Islam.

lkatan perkawinan menimbulkan akibat hukum terhadap diri masing-masing suami isteri, maupun akibat berupa hubungan hukum diantara suami dan istri yang berupa hak dan kewajiban. Pada salah satu isi perjanjian kawin adat disebutkan bahwa apabila salah satu dari kedua belah

\footnotetext{
${ }^{19}$ Hasil wawancara dengan Jainal Rakhim pada tanggal 8-7-2020 di Kuala Kurun, Jainal Rakhim ini pernah melaksanakan pernikahan secara adat dayak.
} 
pihak ada yang meninggal dunia dan memiliki anak, maka segala harta milik mereka akan menjadi hak milik anak dan ahli waris tidak berhak menerima.

Menurut adat istiadat Desa Sarerangan Kecamatan Tewah apabila seorang manusia meninggal dunia, maka diatur dikalangan suku Dayak ada ahli waris, pewaris dan warisan. Sedangkan ahli warisnya adalah anak, cucu, anak angkat, anak kandung, saudara seibu sebapak, ibu atau bapak atau istri yang berhak mutlak. Dan yang berhak menerima warisan utama yaitu sang anak kandung. Anak angkat, saudara/saudara, ibu/bapak. Dalam dekade akhir ini, surat kawin selalu disebutkan bila yang bersangkutan meninggal dunia untuk siapa warisan diberikan.

Hukum Islam sebagai tatanan hukum yang dipegang dan ditaati oleh mayoritas penduduk dan rakyat Indonesia adalah hukum yang telah hidup di dalam masyarakat, merupakan sebagian dari ajaran dan keyakinan Islam dan ada dalam kehidupan nasional serta merupakan bahan dalam pembinaan dan pengembangannya. Berdasarkan sumber ajarannya, realitas kehidupan hukum masyarakat, sejarah pertumbuhanya, dan pcrkembagan hukum di Indonesia, yang menyangkut teori berlakunya hukum Islam di lndonesia terlihat beberapa teori yang sudah mantap dan dalam pertumbuhan.

Berdasarkan sumber ajaran Islam tingkatan kehidupan seorang Muslim dikaitkan dengan sikap dan ketaatannya kepada ketentuan Allah dan Rasul-Nya. Tradisi yang ada dalam suatu daerah memadu penanda bahwa kebudayaan itu harus dijaga dan dilestarikan selama tidak bertentangan dengan nilai-nilai keislaman. Kebiasaan masyarakat Dayak muslim kebanyakan merupakan peninggalan agama Hindu Kaharingan. Kebiasaan ini jika dilihat dari konteks keislaman dalam hal ini hukum Islam maka harus dikelompokkan dalam kelompok 'urf.

Hukum Islam 'urf terbagi kepada 2 (dua) macam yakni 'urf shahih dan 'urf fasid. 'urf shahih adalah sesuatu yang sudah dikenal di masyarakat dan tidak bertentangan dengan dalil syara' karena tidak menghalalkan yang haram dan tidak membatalkan yang wajib, sebagai contoh tujuan dari adanya perjanjian perkawinan yakni untuk menjaga adat-istiadat dan mengurangi terjadinya perceraian antara suami isteri dikemudian hari. Sedangkan 'urf fasid adalah sesuatu yang sudah dikenal di masyarakat, tetapi bertentangan dengan syara' atau menghalalkan yang haram dan membatalkan yang wajib, sebagai contoh adanya perkawinan adat (perjanjian adat) sebelum melakukan perkawinan secara islami, sehingga mereka sah secara adat untuk berkumpul tetapi belum syah secara lslam.

Hal inilah adat yang bertentangan dengan hukum Islam. sehingga jika orang Islam menerima agama Islam sebagai agamanya, ia akan menerima otoritas hukum Islam kepada dirinya dan taat dalam menjalankan syariat Islam. Jadi, setelah melihat semua hasil data yang di peroleh yaitu dengan metode wawancara, observasi dan dokumentasi.

Agar dapat menghasilkan data yang valid peneliti menguji dan menyinpulkan bahwa masyarakat Dayak muslim desa Sarerangan Kecamatan Tewah belum memahami hukum Islam dengan baik. Karena dilihat dengan adanya adat kebiasaan ('urf) yang dipertahankan oleh masyarakat muslim desa Sarerangan yakni adanya perjanjian perkawinan sebelum nikah secara Islami dilangsungkan, tenggang waktu antara keduanya selama 5 sampai 7 hari dan pasangan pengantin tersebut dibiarkan hidup bersama.

\section{Penutup}

Persyaratan pernikahan adat dayak ada 17 poin dan ini cukup berat bagi mempelai lakilaki, oleh sebab itu jangan dipaksakan terutama bagi calon mempelai laki-laki yang kurang 
mampu. Mengingat pernikahan adat dayak itu banyak bersumber dari agama Hindu Kaharingan dan di antaranya ada yang bertentangan dengan hukum Islam, sebaiknya bagi yang menikah itu beragama muslim maka ketika membuka lawang sekepeng itu minum tuak diganti dengan minum susu atau minuman lainnya yang halal. Jika ada hukum adat yang bertentangan dengan hukum Islam maka sebaiknya hukum adat dikalahkan, seperti nikah beda agama dan nikah di bawah umur serta nikah adat kemudian berkumpul sebagaimana suami isteri sebelum nikah secara Islam.

\section{DAFTAR PUSTAKA}

Khalaf, Abdul Wahhab, Ilmu Ushul Fikih, (Jakarta: Darul Qalam, 2002).

Mulyana, Deddy dan Jalaluddin Rakhmat (ed.), Komunikasi Antarbudaya, (Bandung: PT. Remaja Rosdakarya, 2001).

Djazuli, Ilmu Fiqh, (Jakarta: Pranata Media Group, 2010).

Geertz, Hildred, Sebagaimana dikutif oleh Ahrajal, dkk, "Perubahan Pernikahan Adat Suku Bungku di Desa Bahomoleo Kecamatan Bungku Tengah Kabupaten Morowali”, Makalah, Tidak Terbit.

Romli, Khomsahrial, "Akulturasi dan Asimilasi Dalam Kontek Interaksi Antar Etnik", Jurnal Ijtimaiyya, Vol. 8, No. 1, Februari 2015.

Koentjaraningrat, Pengantar Ilmu Antropologi, (Jakarta: Rineka Cipta, 2005).

Puji, Lelay Nangkai, "Nilai Budaya Dalam Tradisi Lisan Pernikahan Adat Dayak Maanyan Di Kalimantan Tengah (Cultural Value in Oral Tradition of Dayak Manyan Customary Marriage in Central Kalimantan", Makalah.

Zahrah, Muhammad Abu, Ushul Fiqh, (Jakarta: Pustaka Firdaus, 2007).

Haroen, Nasrun, Ushul Fiqh 1, (Jakarta: Logos, 1996).

Sadiani, dkk, Jalan Hadat Perkawinan Dayak Ngaju Suatu Upaya Mengawal Harmonisasi Rumah Tangga Dalam Perspektif Hukum Perkawinan Islam, Hasil Penelitian, Tidak Terbit, (IAIN Palangka Raya, 2017).

Effendi, Satria dan M Zein, Ushul Fiqh, (Jakarta: Kencana, 2005).

Santi, "Akibat Hukum Putusan Mahkamah Konstitusi Nomor 46/PUU-VIII/2010 terhadap Hak Anak Biologis dalam Tinjauan Hukum Islam (Pesrpektif Hakim Pegadilan Agama Palangka Raya)", Skripsi, (IAIN Palangka Raya, 2014).

Soekanto, Soejono, Sosiologi: Suatu Pengantar, (Jakarta: Rajawali Grafindo Persada, 1983).

Thoyib, "Eksestensi Perjanjian Perkwinan Adat Dayak Ngaju Dalam Mencegah Perceraian Pasca Putusan Pengadilan Agama Palangka Raya”, Tesis, (Pasca Sarjana IAIN Palangka Raya, tidak diterbitkan, 2017). 